\title{
(i)
}

This work is licensed under a Creative Commons Attribution 4.0 International License https://creativecommons.org/licenses/by/4.0/

https://doi.org/10.24833/2687-0126-2021-3-3-10-18

\section{CODIFICATION OF TERMINOLOGY: A CASE STUDY OF ENGLISH LEGAL TERMS}

\author{
Alexandra G. Anisimova \\ Lomonosov Moscow State University (Moscow, Russia) \\ anissimova@list.ru \\ Nataliya Yu. Tikhonova \\ Financial University at the Government of the Russian Federation (Moscow, Russia) \\ Lomonosov Moscow State University (Moscow, Russia) \\ natatih1994@yandex.ru
}

\begin{abstract}
The present paper is devoted to the phenomenon of codification and the main inconsistencies between the theoretical requirements for a term and actual terminological units found in terminological dictionaries of law. The paper presents the analysis of terms used in the legal sphere. The objective of the research is to identify and classify the inconsistencies that have a direct impact on codification as the last stage of the creation of a terminological dictionary. Particular attention is paid to the study of the content plane of legal terms listed in English terminological dictionaries as well as their expression plane. The authors conclude that at both levels (those of the content plane and the expression plane) and at the level of functioning the inconsistencies raise important issues concerning further development of both terminography as a field of science and the dictionary-making process taking place today.
\end{abstract}

Key words: terminological dictionary, codification, legal term, polysemantic term, synonymous term, diatopic variation, professional jargon, content plane, expression plane.

How to cite this article: Anisimova A.G., Tikhonova N.Yu. (2021). Codification of Terminology: a Case Study of English Legal Terms. Professional Discourse \& Communication, 3(3), pp. 10-18. (in Russian). https://doi.org/10.24833/2687-0126-2021-3-3-10-18

\section{INTRODUCTION}

hroughout the history of terminology studies, certain requirements have been imposed on the notion of a term, both from the point of view of the content plane and from the point of view of the expression plane. The level of functioning is no less important and a number of requirements for a terminological unit are observed at this level as well. In accordance with the theory developed by S.V. Grinev-Grinevich, the main requirements for the form, content and 
functioning of a term include semantic consistency of the term as well as its unambiguity within the given terminology, invariance, absence of synonyms and compliance with the norms of the language, for which reason professional jargon should be avoided [Grinev-Grinevich, 2008]. However, it is usually extremely problematic to comply with all these requirements.

One of the most important areas in the field of terminology is the process of the collection of terms within a specific sphere of knowledge followed by their description, i.e. the creation of the inventory of terms. The collection and description are followed by the harmonization stage when the given terminology is shown as a unified system. Finally, comes the last stage called codification, i. e. the creation of a standardized terminological dictionary [Graudina \& Shiryaev, 1999].

Various terminological dictionaries (explanatory, etymological, historical, frequency dictionaries, translation dictionaries, etc.) compiled by an author or a group of authors are published as a result of harmonization and systematization of terms. Terminological dictionaries are the main source of specialized vocabularies of a particular language. Consequently, the emergence of terminography in the 1980s and its further development as a science of compiling terminological dictionaries is indispensable.

\section{THEORETICAL BACKGROUND OF THE STUDY}

Terminography as a relatively modern science of dictionary-making including all the key stages of the process was created and further developed by a number of Russian and foreign scholars such as Yu. N. Marchuk [Marchuk, 1992], S.V. Grinev-Grinevich [Grinev-Grinevich, 2008], S. D. Shelov [Shelov, 2018], V. M. Leychik [Leychik, 2006], A. S. Gerd [Gerd, 1986], E. L. Khokhlova [Khokhlova, 2005], M. Lukasik [Lukasik, 2012], V. V. Dubichinskij [Dubichinskij, 2020]. It seems particularly important to recognize that while theoretical foundations are put forward by the scholars, actual practical work that will be assessed by readers is performed by authors or compilers of terminological dictionaries. The most crucial stage of this work that has an immediate impact on the overall result is undoubtedly codification.

The purpose of this paper is to analyze the problem of codification of terminological units, with a particular focus on the most challenging cases. A key assumption to be taken into account for the purposes of this analysis is that the paper is not concerned with the codification of linguistic norms related to syntax, morphology, orthography or orthoepy, but is concerned with the codification of a particular part of the English language vocabulary. As is the case with terminology, codification is an essential stage of work with the aim of the systematization of specialized vocabulary in the form of a terminological dictionary. Therefore, discussions concerning negative consequences of codification are considered unreasonable. When studying terminology, researchers do not focus on the ability of the language to develop. A dictionary created as a result of the progressive work primarily reflects the transformations that have taken place in the language, but does not directly affect them.

Moreover, terms in general and legal terms in particular follow the established rules in their various aspects: terminological units frequently have a specific author (lawyers, judges, etc.) or a clearly traceable reason for their emergence (court decisions, new precedents, new types of criminal offences related to the development of technology), their semantics is clearly defined and restricted by specialists in a particular field to avoid misunderstanding in professional communication. If necessary, transformations within terminology may also take place when experts make a decision stating that certain terms should not be used any more due to the loss of the corresponding 
extralinguistic realities. There is no doubt that codification makes it possible to get a dictionary that meets the needs and expectations of readers including professionals of a particular field.

The stage of codification is also of utmost importance since it is at this stage that the author encounters difficulties connected with the failure to satisfy all the requirements for a term. Consequently, terminological units cannot be called perfect and the reflection of these imperfections is observed in the corresponding terminological dictionaries.

Therefore, the purpose of this paper is not only to carefully study the issue of terminological codification but also to identify and classify the main inconsistencies between real terms and the requirements for terminological units found in a number of terminological dictionaries of law published in the UK and the USA.

\section{MATERIAL AND METHODS}

The material for the research includes English legal terms recorded in the following authoritative terminological dictionaries: Black's Law Dictionary [Garner, 2004], Oxford Dictionary of Law [Law \& Martin, 2009], Collins Dictionary of Law [Stewart \& Burgess, 2002], The Longman Dictionary of Law [Curzon \& Richards, 2007], Oran's Dictionary of the Law [Oran, 2000], Nonprofit Law Dictionary [Hopkins, 2015], as well as online Merriam-Webster's Law Dictionary (https://www.merriam-webster.com/legal). These dictionaries have been published in the last 20 years and reflect the current situation in the legal terminology of the English language. Macmillan Online Dictionary (https://www.macmillandictionary.com/) and Oxford Online Advanced Learner's Dictionary (https://www.oxfordlearnersdictionaries.com/) are also involved in the analysis as non-terminological English dictionaries.

For the research, the method of definitional analysis has been used, which allowed us to specify semantic relations within English legal terms. However, a definition does not always provide the complete insight into the meaning of a term. Therefore, the method of descriptive analysis has also been used in the research in order to establish a framework for advanced analysis of meanings of the terminological units of law.

\section{RESULTS AND DISCUSSION}

The inconsistencies between the requirements for terms and real units found in written sources can be classified in the same way as those requirements, i. e. the inconsistencies at the level of the content plane, the inconsistencies at the level of the expression plane, the inconsistencies at the level of functioning.

At the level of the content plane, the inconsistencies identified during the extensive research include first of all:

- the semantic discrepancy between the terminological unit and the corresponding word of everyday language.

Legal terminology is characterized by a large number of consubstantial terms, i. e. terms that originated in the everyday language, and such discrepancies between a special word and an everyday word are inevitable. It is of paramount importance to differentiate between terminological and general vocabulary. The majority of terms of the Humanities are consubstantial, i.e. they can be found both in terminological and general vocabulary, and to differentiate between a term and a word of the general language it is necessary to use the definability test. This test was developed by the scholars of the English department of Lomonosov Moscow State University. The main idea of 
this test is to compare the definition of a certain term given in a specialized terminological dictionary with its description in a general language dictionary.

There are many examples of the discrepancy between a term and the corresponding word of everyday language when it comes to significant 'narrowing' of the semantics of a terminological unit in comparison with the corresponding word of everyday language. So-called 'narrowing' makes it possible to imagine, to a certain extent, that the terminological meaning can be considered a semantic element of the general meaning. Consider the following examples and their definitions:

\section{list (s)}

- as an everyday language word in a general language dictionary "sets of names, numbers etc. that are written or printed one below another" [Macmillan Dictionary];

- as a legal term in a specialized dictionary of law "calendars of cases awaiting trial" [Law \& Martin, 2009, p. 220].

plea

- as an everyday language word in a general language dictionary "an urgent or emotional request for something" [Macmillan Dictionary];

- as a legal term in a specialized dictionary of law "in criminal proceedings, a formal statement made in court by an accused person as a response to the charge made against him" [Law \& Martin, 2009, p. 408].

\section{cruelty}

- as an everyday language word in a general language dictionary "behavior that deliberately causes pain to other people or animals, or that makes them unhappy or upset" [Macmillan Dictionary];

- as a legal term in a specialized dictionary of law "behavior serious enough to injure a spouse's physical or mental health" [Law \& Martin, 2009, p. 148].

In each case it is possible to identify a common seme that can combine the two meanings as sharing some underlying concept: with the word lists it is the idea of "a group of things, facts, ideas, principles of the same type", with the word plea - "a statement reflecting someone's need or clarifying someone's position", with the word cruelty - "violent behaviour".

The following question can be raised: is it absolutely necessary for legal dictionaries to include one more meaning that is not related to law? It can be concluded that it is not sensible to include the general meaning in a terminological dictionary, which is usually avoided since the compilers of dictionaries have already agreed on the fact that the information that is not directly related to a particular professional field is considered unnecessary for a terminological dictionary and of zero professional value.

The next inconsistency at the level of the content plane is:

- a large number of polysemantic terms.

Reflecting on the phenomenon of polysemy, scholars suggest a broad variety of reasons. The main problem probably arises from "the reluctance of social scientists to accept neologisms, i.e. new words, phrases or acronyms that can unambiguously name a concept. Because of this reluctance, new meanings are often stipulated for old words, leading to polysemy" [Zgusta, 2006]. This point of view is supported by a number of western scholars [Catford, 1978; Chesterman, 1997; Fawcett, 1998; Maurais \& Morris, 2004]. In numerous terminology studies [Reformatsky, 2004; Lotte, 1968; Akhmanova, 1979; Gvishiani, 1993], Russian scholars express various opinions concerning this issue. At the same time, they consistently single out two primary reasons:

- the emergence of a new concept that has features resembling the concept already named by this term; 
- the development and modification of the concept which is followed by the splitting of the semantics of the terminological unit.

The traditional point of view on polysemy in terminology is as follows: terms coinciding in form but having different meanings within the same terminological system are polysemantic. If the same situation is observed in two different terminological systems, the terms are homonyms.

With polysemy brought into focus, the question arises about the order of meanings as well as about their hierarchy. Therefore, frequency of use of terminological units with particular semantics is given a crucial role. Consequently, it seems logical to establish a link between codification as a stage of a dictionary creation process and corpus-based studies that help to find out the frequency of use of a term with a certain meaning. However, according to another point of view, the first dictionary entry should demonstrate the meaning that developed in the language earlier than others. Thus, chronology and frequency may contradict one another as criteria for the most appropriate order of meanings.

The examples of polysemantic terms are numerous; the order of meanings in two different dictionaries varies:

In the Merriam-Webster's Law Dictionary online (https://www.merriam-webster.com/legal):

judiciary I "the court system";

judiciary II "the branch of government in which judges serve";

judiciary III "the judges in a particular court system or in all court systems".

In the Black's Law Dictionary [Garner, 2004, p. 2480-2481]:

judiciary I "the branch of government responsible for interpreting the laws and administering justice"

judiciary II "a system of courts";

judiciary III "a body of judges".

Thus, the first and second meanings of the term in these dictionaries are given in the reverse order, while the third meaning is the same.

In the Oxford Dictionary of Law [Law \& Martin, 2009, p. 307-308]:

jurisdiction I "the power of a court to hear and decide a case or make a certain order";

jurisdiction II "the territorial limits within which the jurisdiction of a court may be exercised";

jurisdiction III "the territorial scope of the legislative competence of Parliament".

In the Black's Law Dictionary [Garner, 2004, p. 2490-2497]:

jurisdiction I "a government's general power to exercise authority over all persons and things within its territory";

jurisdiction II "a court's power to decide a case or issue a decree" (the right of a court to decide on a case or issue a ruling; administration of justice);

jurisdiction III "a geographic area within which political or judicial authority may be exercised";

jurisdiction IV "a political or judicial subdivision within such an area".

Although an 'ideal' term should be independent of the context, more often than not it is the context that makes it possible to distinguish between several meanings of polysemantic terms. Moreover, by the notion of context different dictionaries mean different things. While traditionally context includes the words surrounding a particular word, some compilers of terminological dictionaries interpret context as the very field of the application of a term. The given examples demonstrate that the number of meanings in the two dictionaries is not identical either. Besides, a 
number of dictionaries record meanings of terms only acceptable in a certain region or community. Finally, the meaning recorded in one dictionary may not be found in another because it is rather narrow and is included in a more general meaning in another reference book.

In the Oxford Dictionary of Law [Law \& Martin, 2009, p. 322]:

legislation I "the whole or any part of a country's written law";

legislation II "the process of making written law".

In the Black's Law Dictionary [Garner, 2004, p. 2635-2636]:

legislation I "the process of making or enacting a positive law in written form";

legislation II "the law so enacted";

legislation III "the whole body of enacted laws".

The number of identified meanings in different terminological dictionaries is different too, which can be explained by several reasons. Firstly, narrow meanings of the term can be combined. Secondly, by contrast, the general meaning of a terminological unit can be given in different dictionary entries. Both processes provide a range of meanings arranged in a different order. For example, in the Oxford Dictionary of Law [Law \& Martin, 2009, p. 425]:

privilege I "a special right or immunity in connection with legal proceedings conferred upon a person by virtue of his rank or office";

privilege II "the right of a witness when testifying to refuse to answer certain types of question, or of a party when disclosing documents to withhold disclosure or inspection of certain types of documents on the ground of some special interest recognized by law".

In the Black's Law Dictionary [Garner, 2004, p. 3790-3795]:

privilege I "a special legal right, exemption, or immunity granted to a person or class of persons; an exception to a duty";

privilege II "an affirmative defense by which a defendant acknowledges at least part of the conduct complained of but asserts that the defendant's conduct was authorized or sanctioned by law";

privilege III "a rule that gives a witness the option to not disclose the fact asked for, even though it might be relevant; the right to prevent disclosure of certain information in court".

The latter dictionary contains a meaning not recorded in the former reference book, which is characterised as being semantically narrow without a direct equivalent in the target language.

Another inconsistency at the level of the content plane is:

- a large number of synonymous terms, for instance:

crime - offence - criminal offence;

cross-examination - cross-interrogation;

insider trading - insider dealing;

tenancy - lease;

third countries - third world.

A considerable number of dictionary entries include references to synonymous terminological units with the aim of facilitating productive use of the dictionary and better systematization. Some synonyms are provided with a specific dictionary entry because there is a crucial difference in semantics, while some are only mentioned among other terminological units.

At the level of the expression plane, after the analysis of a number of dictionaries, numerous pairs of terms characterized by different spellings (usually differing in one letter only) have been found in British and American diatopic variants of the English language, as, for example, in the following terminological units belonging to British English and American English respectively: 
offence - offense;

judgement - judgment;

defence - defense;

misdemeanour - misdemeanor;

(Your) Honour - (Your) Honor.

Spelling naturally depends on the country where the dictionary was released, but there are certain editions that include both British English and American English variants.

At the level of functioning, the study of specialized dictionaries has demonstrated that some books include professional jargon as an important part of the English legal terminology:

rabbit - runaway criminal;

snitch - informant;

mole - informant, double agent;

five-o - policeman, cop;

bagman - racketeer;

ghetto penthouse - upper bunk (literally ghetto-penthouse);

hats and bats - prison guards.

\section{CONCLUSION}

Terminology is a core area in professional and business discourse, and it requires careful attention and consideration. Discrepancies between requirements for a term as the basic unit of terminology and real terms recorded in dictionaries can be observed at all levels.

At the level of the content plane, inconsistencies between the requirements for a term and existing terminological units found in specialized English legal dictionaries include:

- semantic discrepancy between the term and the word of the general language;

- a large number of polysemantic and synonymous terms.

At the level of the expression plane, the analysis has shown that there are a great number of pairs of terms with two different spellings in British English and American English.

At the level of functioning, specialized dictionaries include professional jargon as one of the integral parts of the English terminology of law.

The research concludes that terminographic work in the course of the codification of legal terms in dictionaries, has an excellent prospect for development and improvement. There are still debates concerning the issue whether it is chronology or frequency that should be the preferable criterion when listing the meanings of a polysemantic term as well as concerning different reasons for including either all existing synonyms in a dictionary entry or only some of them. Moreover, regional spellings of the same term and professional jargon are sometimes not considered to be worth including in an entry either. Codification work aimed at improving the existing dictionaries increases their overall quality and is extremely important for the compilers of new terminological dictionaries.

\section{Conflict of Interest}

The authors declare that they have no conflict of interest 


\section{REFERENCES}

1. Akhmanova, O.S. (1979). Lingvistika i semiotika [Linguistics and Semiotics]. Moscow: Izd-vo MGU (in Russian).

2. Apresjan, Yu. (2000). Systematic Lexicography. Translated by Kevin Windle. Oxford: Oxford University Press.

3. Atkins, B.T., \& Rundell, M. (2008). The Oxford Guide to Practical Lexicography. Oxford: Oxford University Press.

4. Bergenholtz, H., \& Tarp, S. (1995). Manual of Specialised Lexicography: The Preparation of Specialised Dictionaries. Amsterdam/Philadelphia: John Benjamins Publishing Company.

5. Catford, J.C. (1978). A Linguistic Theory of Translation. An Essay in Applied Linguistics. Oxford: Oxford University Press.

6. Chesterman, A. (1997). Memes of Translation: The Spread of Ideas in Translation Theory. Amsterdam: John Benjamins.

7. Curzon, L.B., \& Richards, P.H. (2007). The Longman Dictionary of Law. 7th ed. Pearson Longman.

8. Fawcett, P. (1998). Ideology and Translation. In M. Baker (Ed.). Routledge Encyclopedia of Translation Studies (pp. 106-110), London: Routledge.

9. Garner, B. A. (2004). Black's Law Dictionary. 8th ed. West Publishing Co.

10. Gerd, A. (1986). Osnovy nauchno-tekhnicheskoj leksikografii (Kak rabotat' nad terminologicheskim slovaryom) [Fundamentals of Scientific and Technical Lexicography (How to Work on a Terminological Dictionary)]. Leningrad: Izd-vo LGU (in Russian).

11. Graudina, L.K., Shiryaev, E.N. (1999). Kul'tura russkoj rechi. Uchebnik dlja vuzov [The Culture of Russian Speech. A Coursebook for High Schools]. Moscow: NORMA-INFRA (in Russian).

12. Grinev-Grinevich, S.V. (2008). Terminovedenie [Terminology Studies]. Moscow (in Russian).

13. Gvishiani, N.B. (1993). Terminology in English Language Teaching (with a Glossary of Russian-English Linguistic Terms). Moscow: Vysshaja Shkola.

14. De Groot, G.-R., \& van Laer, C. J. P. (2006). The Dubious Quality of Legal Dictionaries. International Journal of Legal Information: The Official Journal of the International Association of Law Libraries, 34 (1), 65-86.

15. Dubichinskij, V. (2020). Nekotorye Sovremennye Voprosy Terminografii [Some of the Modern Issues of Terminography]. Rasprave, 46/2, 547-566 (in Russian).

16. Hopkins, B. R. (2015). Nonprofit Law Dictionary. Wiley.

17. Khokhlova, E.L. (2005). Soderzhanie terminologicheskogo polya v mnogoyazychnoj terminografi: primenitel'no $k$ istoricheskoj terminologii v anglijskom, francuzskom, nemeckom i russkom yazykah [The Contents of Terminology Field in Multilingual Terminography: A Case Study of History Terminology in English, French, German and Russian]. Moscow (in Russian).

18. Law, J., \& Martin, E.A. (2009). A Dictionary of Law. Oxford: Oxford University Press.

19. Lotte, D.S. (1968). Kak rabotat' nad terminologiej. Osnovy i metody [How to Work on Terminology. Fundamentals and Methods]. Moscow: Nauka (in Russian).

20. Lejchik, V.M. (2007). Terminovedenie: predmet, metody, struktura [Terminology Studies: Subject, Methods, Structure]. Moscow: URSS (in Russian).

21. Lukasik, M. (2012). Terminological Dictionary as a Comprehensive Cognitive and Linguistic Tool. Language in Different Contexts: Research Papers, 5 (1), 98-108.

22. Macmillan Online Dictionary. Retrieved from https://www.macmillandictionary.com/ (accessed: 15 May, 2021). 
23. Marchuk, Yu.N. (1992). Osnovy terminografii [Fundamentals of Terminography]. Moscow: Izd-vo MGU (in Russian).

24. Maurais, J., \& Morris, M. (2004). Languages in a Globalising World. Cambridge: Cambridge University Press.

25. Merriam-Webster's Law Dictionary. Retrieved from https://www.merriam-webster.com/legal (accessed: 15 May, 2021).

26. Oran, D. (2000). Oran's Dictionary of the Law. West Legal Studies Thomson Learning.

27. Oxford Online Advanced Learner's Dictionary. Retrieved from https://www.oxfordlearnersdictionaries.com/ (accessed: 15 May, 2021).

28. Reformatsky, A.A. (2004). Vvedenie v yazykovedenie: uchebnik dlja vuzov [Introduction to Linguistics: A Coursebook for High Schools], 6th edition. Ed. by V.A. Vinogradova. Moscow: Aspekt Press (in Russian).

29. Shelov, S.D (2018). Ocherk teorii terminologii: sostav, ponyatijnaya organizaciya, prakticheskie prilozheniya [Review of the Theory of Terminology: Composition, Conceptual Organisation, Practical Applications]. Moscow: PrintPro (in Russian).

30. Stewart, W.J., \& Burgess, R. (2002). Collins Dictionary of Law. Harper Collins Publishers.

31. Van Sterkenburg, P. (2003). A Practical Guide to Lexicography. Amsterdam/Philadelphia: John Benjamins Publishing Company.

32. Zakirova, E.S. (2013). Terminografiya kak rezul'tat formirovaniya yazyka dlya special'nyh celej [Terminography as a Result of the Formation of a Language for Specific Purposes]. Izvestiya MGTU "MAMI", 4 (18), 2 (in Russian).

33. Zgusta, L. (2006). Lexicography Then and Now: Selected Essays. In F.S.F. Dolezal \& Th.B.I. Creamer (Eds.). International Journal of Lexicography, 19(4) (pp. 483-487), Tübingen: Max Niemeyer.

\section{About the authors:}

Alexandra G. Anisimova is Dr. Sci. (Philology), professor in the Department of English linguistics at Lomonosov Moscow State University (Moscow, Russia).

Nataliya Yu. Tikhonova is senior lecturer at Financial University at the Government of the Russian Federation (Moscow, Russia) and PhD researcher at Lomonosov Moscow State University (Moscow, Russia). 